\title{
APPLICATION OF A PRACTICAL METHOD TO RECUPERATE THE CHEMICAL COMPONENTS OF USED BATTERIES
}

\author{
Ma. Neftalí Rojas-Valencia \\ Ma. Guadalupe Urquiza-Moreno \\ Cristian Ríos-Martinez \\ National Autonomous University of Mexico, Mexico.
}

\begin{abstract}
In Mexico, an estimated 450 million batteries are used each year. In the last 43 years, approximately 635 thousand tons of batteries have been released into the environment. Up to date there are no regulations for their proper management, creating potential risks for both human and environmental health. With the purpose of contributing to the alleviation of this problem, the objective of this work was to identify a practical method to recuperate the chemical components of discarded batteries and to conduct laboratory experiments for the recuperation of metals.

Six methods for the treatment of batteries were compared: 1) electrochemical recuperation of nickel and cadmium, 2) dissolution of batteries in an acidic solution (DBAS), 3) differential pulse polarography, 4) pirolysis, 5) application of chemical stabilization agents, and 6) reduction of battery components to pulp.

The method applied in this study, was the DBAS. The batteries were classified, cleaned, and weighed. Their outer cover was removed, the batteries were dissected to extract internal components, and the dissolution of the battery components was carried out in $30 \mathrm{~mL}$ of concentrated nitric acid (HNO@) for each cylindrical battery and for each five button batteries. The extraction with magnetic agitation was carried out over four hours under an exhaust hood, and the toxic gases that were released were bubbled through water. The resulting solution was measured for metals according to EPA method $6010 \mathrm{~B}$, using a Jarrell Duo Inductively Coupled Plasma Emission Spectrophotometer.

The metals extracted using this technique were, from the button batteries, $\mathrm{Cu}, \mathrm{Fe}, \mathrm{Pb}$, and $\mathrm{Zn}$, from cylindrical Rocket batteries, $\mathrm{Cu}, \mathrm{Pb}, \mathrm{Zn}, \mathrm{Cr}, \mathrm{Ni}, \mathrm{Ag}$ and from Duracell batteries, $\mathrm{Cu}, \mathrm{Fe}$, $\mathrm{Pb}$, and $\mathrm{Zn}$. The concentrations and weights varied with the brand and type of batteries. It is recommended that studies need to be done regarding the purification of these metals with the purpose of commercialization.
\end{abstract}

\section{KEYWORDS}

Practical method; Chemical components, Used batteries.

\section{INTRODUCTION}

Batteries are electrochemical devices or portable generators with the capacity to convert chemical energy into electrical energy. A basic battery if formed by an anode (positive electrode), a cathode (negative electrode), and an electrolyte (liquid solution through which an electric current can travel). The potentially dangerous components of batteries include: mercury, lead, copper, zinc, cadmium, manganese, nickel, and lithium [1, 2]. 
The use of batteries is ubiquitous. In Mexico it is estimated that 450 million batteries are used annually. They are everywhere; their disappearance would have severe consequences, from someone not waking up because their alarm clock never rang to the death of someone who uses a pacemaker.

At the end of their lives, batteries are generally discarded in trashcans, where, due to humidity, they corrode, freeing heavy metals and toxic compounds that pollute soils and bodies of surface or ground water. One alkaline battery can contaminate 175,000 liters of water, a zinc-carbon battery 3,000 liters, a zinc-air 12,000 liters, a silver oxide 14,000 liters, and a single watch battery is capable of contaminating a half million liters, while a mercury button micro-battery can contaminate 6.5 million liters of water. Furthermore, a common battery can contaminate the amount of water one family needs throughout its entire life $[3,4$, $5]$.

It is estimated that between 1995 and 200335,500 tons of battery wastes were generated annually. More than 500 million legally imported batteries are consumed annually, and approximately 300 million illegally-imported batteries are used. By the last 43 years, 635,000 tonnes of batteries have been discarded. The contents of these include elements that have innocuous effects on health and the environment (in appropriate quantities), such as carbon (C) and zinc $(\mathrm{Zn})$. Batteries also release elements that can represent risks due to the large volume of the compounds that is emitted, including the 145,918 tons of manganese dioxide $(\mathrm{MnO} 2)$ and other toxic elements such as 1,232 tons of mercury $(\mathrm{Hg}), 22,063$ tons of nickel (Ni), 20, 169 tons of cadmium $(\mathrm{Cd})$, and 77 tons of lithium compounds $[3,5,6]$.

Various attempts have been made to instate programs for the collection of used batteries in cities throughout Mexico. There have been school-based initiatives, as well as programs in shopping centers and through civil organizations. Certain academic sectors have attempted to develop technology for the safe disposal or recycle of batteries, but without apparent success. As such, the objective of this work was to identify a practical methodology to recuperate chemical components of used batteries, and to carry out tests for the recuperation of metals in the laboratory.

\section{MATERIALS AND METHODS}

\subsection{First Phase.}

The first phase was a study to identify and compare different treatment alternatives for batteries in Mexico. Various sources were consulted:

The database of the National Institute of Statistics, Geography, and Information, INEGI, XVI Industrial Census, in which sales represented $93 \%$ of production [7].

The market study carried out by the Federal Procurement for the Consumer, PROFECO [8].

The Regulations set by the General Law of Ecological Equilibrium and Environmental Protection from Dangerous Solid Wastes (D.O. 25-88) and the Regulation for the Terrestrial Transport of Materials and Dangerous Wastes (D.O. 7-IV-93) [9].

For the technical specifications, collection, storage, transport, reuse, recycling, treatment, and final disposal, The Official Mexican Norm NOM-052-ECOL-93 was consulted. This law established the characteristics of dangerous residues, predicting the criteria and classification lists, and the limits that are made on a dangerous waste due to its environmental toxicity [10]. 
- To ascertain the legally applicable framework for the procedure of collection and recycling of batteries, the General Law for Ecological Equilibrium and Environmental Protection (D.O. 28-I reformed D.O. 13-XII-96, Chapter VI), was used.

- This search included the database of CONACYT, including the Information System of Scientific Projects and Technologies in the Environmental Area (SICTA).

\subsection{Second Phase}

The second phase was carried out at the laboratory level. The steps followed were the following:

To avoid interference from metals, all of the glass material used was washed with a solution of phosphate-free Extran, after which the materials were submerged in a solution of $10 \%$ $\mathrm{HNO}_{3}$ for 12 hours, after which they were rinsed with distilled water and left to dry.

In the method selected, button and cylinder batteries were used. These were cleaned, classified according to brand and components, separated into each of their parts, and weighed with an Ohaus analytical scale.

The batteries were opened with electrician's pliers and miniature pliers $(103 \mathrm{~mm} \mathrm{41/16"}$ Trufer brand) and were dissected with specialized aluminium and metal-cutting knife (Model Stanley, 10-099), as shown in Figure la-c.

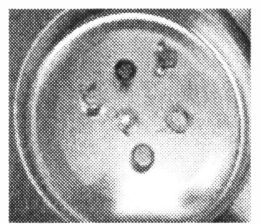

(a)

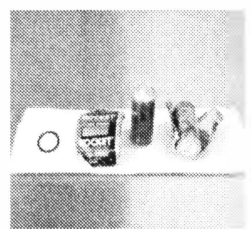

(b)

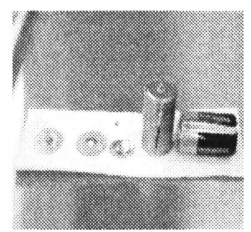

(c)

Figure 1. Cut, dissection, and separation of button battery components: (a) button; (b)rockets and; (c) Duracell batteries

After extracting the internal battery components, these were placed separately into an Erlenmeyer flask and $30 \mathrm{ml}$ of concentrated nitric acid was added. The flasks were immediately capped due to the generation of toxic vapours, which were bubbled through water. This reaction was maintained for 4 hours with magnetic agitation. The extraction was carried out using glass equipment, in a system such as that which is shown in Figure 2. 


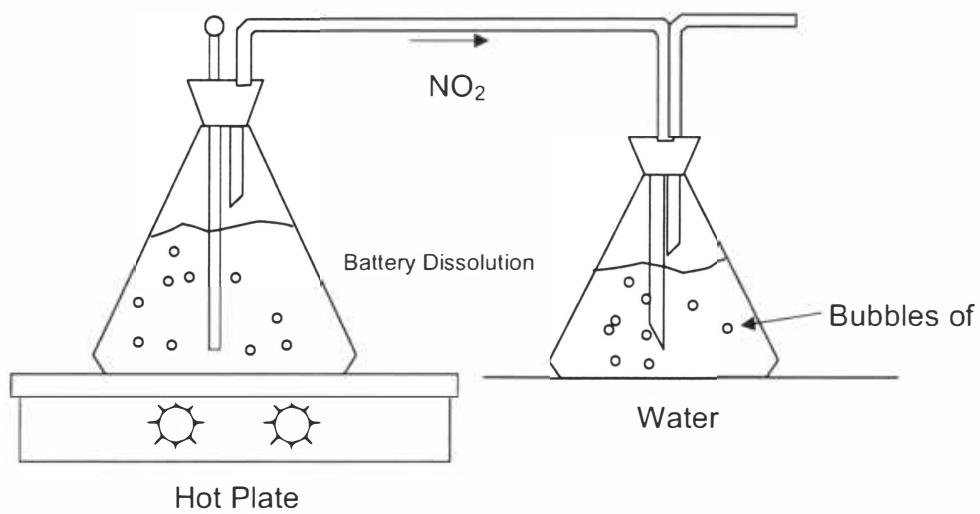

Figure2. Dissolution of common, cylinder, and button batteries

In the three trials that were carried out, an isothermal reaction was registered with a release of toxic vapours (nitrous oxide), which was bubbled through water. Due to the nature of the reaction, the work was done under an extraction hood and with the necessary security measures.

The extraction trials were carried out in the following manner:

1. Button batteries. The covers were removed from five batteries with electrician's pliers. The contents were placed into an Erlenmeyer flask and $30 \mathrm{ml}$ of concentrated nitric acid was added. The flask was immediately capped due to the generation of toxic vapours, which were bubbled through water. This reaction was maintained with magnetic agitation during 4 hours. After this time period, the solution was completely filtered using a Buchner funnel with Whatman no. 4 filter paper. Distilled water was added to the filtrate to reach a total volume of $100 \mathrm{ml}$, for further analysis of metals.

2. After a cleaning, weighing, and removing the cover from three Rocker brand batteries, they were placed in an Erlenmeyer flask, $90 \mathrm{ml}$ of concentrated nitric acid was added, and the same procedure was followed as for the button batteries. The reaction was maintained for 4 hours with magnetic agitation. At the end, the solution, which was black due to the presence of carbon in the batteries, was filtered completely using Whatman no. 4 paper. Distilled water was added to the filtrate to reach a total volume of $200 \mathrm{ml}$, for further analysis of metals.

3. The last extraction was carried out using three Duracell brand batteries using the same treatment as used above. At the end of the extraction period, distilled water was added to a total volume of $200 \mathrm{ml}$ for further analysis of metals.

The metals in the solutions obtained were quantified using an inductively coupled plasma atomic emission spectrophotometer (Jarrell Duo brand). For button batteries, lead, copper, iron, and zinc were quantified; for domestic cylinder, copper, iron, and zinc, and for Asian cylinder, chrome, copper, lead, nickel, mercury, and zinc. 


\section{RESULTS AND DISCUSSION}

\subsection{First Phase Results}

The results of the research done to identify the treatment alternatives for batteries in Mexico, with the aim of diminishing environmental problems, produced various sub themes: a) Actions taken in Mexico to diminish the problem, b) research, c) legal aspects, d) training aspects, and e) social aspects. Nevertheless, for the purposes of this work only the first two were taken into consideration.

\section{Actions taken in Mexico by businesses to diminish the problem}

Enertec Mexico is a business that has earned a "Clean Industry" certificate, which it was awarded on June 3, 2001. Enertec has 5 plants engaged in battery production, and one engaged in battery treatment:

- Torreon Plant, annual production capacity 5.5 million batteries.

- Celaya Plant, annual production capacity 3,780,000 batteries.

- Monterrey Plant, annual production capacity 43,800,000 batteries.

- Escobedo Plant, annual production capacity 936,000 batteries.

- Cienega Plant, annual production capacity 75,000 tons of lead and 85,000 tons of polypropylene.

- San Francisco Plant, annual production capacity 3.5 million batteries.

A company called "Batteries for Recycling" plans to establish itself in Mexico City, in the Iztapalapa zone [11]. It is dedicated to collecting, storing, and transporting batteries of all chemical compositions for the purpose of recycling --except those that contain calcium chromate. It would volunteer service to private institutions such as corporations, universities, and schools. Individuals would pay a fee for the company's services, and Batteries for Recycling would pay a North American company, which is where the battery wastes would be transported. This company still has not commenced operation, as it is still waiting for its necessary operating permits.

TRAIDEC, a French company dedicated to the treatment of batteries for the recuperation of metals, showed, in the year 2000, interest in investing in Mexico by installing a plant in exchange for a contract that would permit it to recuperate its investment through charging fees for the service of recycling batteries that enter its system. The process of pyrolysis used by this company (represented in Mexico by River Biotechnology), transforms dangerous waste into energy. This process, called DTV, which is a method used to treat different dangerous or infectious industrial wastes, consists in:

- Preparation of wastes.

- Thermal dissociation: thermolisis process produces gas and energy.

- Recuperation of materials.

- Combustion from thermolosis.

- Energetic recuperation of the wastes.

The company INMETCO (located in Elwood Pennsylvania) is another business that is interested in expanding its work in Mexico, which includes disposal of nickel and cadmium batteries. This company uses a process called High Temperature Metal Recovery (HTMR). Currently, the company recovers used nickel-cadmium batteries originating in Canada [1 1$]$. 
The company SOGEM has also shown its capacity for exporting used $\mathrm{Ni}-\mathrm{Cd}$ batteries to Korea [11].

It is fitting to clarify here that Mexico, as a member of the OECD, can import and export dangerous waste to member countries for treatment or final disposal. No other Latin American country has this capability, as the others are not signers of the Basel Convention.

One company dedicated to the production of America brand batteries also has the technology to recycle them, and has been awarded a clean industry certification. It has plants in Coahuila, Guanajuato, New Leon, and Tlaxcala. The recycling plant is in Cienega de Flores, Nuevo Leon.

In 1999, Motorola of Mexico began a pilot program for collecting used cell phone batteries that contain nickel and cadmium. The batteries were collected through various cell phone retailers. The collected batteries were transported to the border by the Mexican company RIMSA, and sold for recycling to a company called INMETCO in Pennsylvania [12]. This program used the gift of an antenna to incentivize the public to participate. However, the administrative work involved in exportation, as well as the costs of transport to the recycling plant, discouraged Motorola from continuing with the project.

The Tamaulipeca Network reports a pilot program in which Industrial Fostfato collects batteries. The collection is carried out inside of this company's buildings with the participation of the employees. The pilot program consists in the installation of containers in strategic points throughout the company and in shops around the company. In a period of 8 months, 44 kilos of batteries were collected. However, for this program, the disposal of the batteries was not considered, as the company did not know where to send them.

Businesses that are present in Mexico and have battery collection programs in other countries, such as Radio Shack and Home Mart, do not carry out these programs in Mexico.

The programs mentioned do not consider that, in the case that they would opt for a final disposal, municipalities do no have adequate infrastructure to receive the batteries. Furthermore, any collection program should contemplate a separation of different types of batteries, as each one requires different technology to be disposed of or recycled.

\section{Research developed in Mexico.}

At the research level, few reports were identified on processes related to recycling and reusing batteries. Following is a summary of information found regarding this topic.

1) A study entitled "Electrochemical recovery of cadmium from mixes of nickel and cadmium" is the Masters Thesis of Jimenez [13], assisted by Dr. Jorge Ibanez Cornejo of the Universidad Iberoamericana, Santa Fe Campus. The thesis refers to the development of a process based on electrochemical techniques for the recuperation of cadmium through a nickel-cadmium solution present in rechargeable batteries.

This process is proposed as a technology for the management of cell phone batteries. The costs are not determined.

2) Another report on the development of processes for the recovery of metals from used batteries refers to an undergraduate thesis in Chemical Engineering from the Faculty of Superior Studies Zaragoza, entitled "Design of a reactor batch for the treatment of waste 
batteries," which reports the development of a technique for the treatment of dry batteries through dissolution with nitric acid, with an $80 \%$ success rate [14]. This study was directed by Dr. Eduardo Loyo Arnaud. The method is used principally by personnel and students of the Faculty of Superior Studies Zaragoza. Costs are not reported.

3) Differential pulse polarography. This is a new technique. An analysis of metallic traces is done. Specialized equipment is required as well as highly trained personnel [15]

4) Pyrolysis or DTV. The process of pyrolysis is a method used to treat different dangerous and infectious industrial wastes, and to recuperate energy from the wastes. Used by a private company that represents Traidec in Mexico, and noted in the report "Identification of alternatives for recycling batteries," Secretary of Environment, Natural Resources, and Fish/ National Institute of Ecology/ General Direction of Materials, Wastes, and Dangerous Activities [16].

5) Application of chemical stabilization agents. This method is recommended for anyone who uses batteries.

Three stabilizing chemical agents are added to batteries confined in sealed 100-micron plastic bags. These agents neutralize the dangerous components of the different types of batteries sold. Three stabilizing agents have been found to neutralize lead, mercury, sulfuric acid, and cadmium, the principal contaminants present in the batteries on the market.

- For lead, sodium sulfur $\left(\mathrm{Na}_{2} \mathrm{~S}\right)$ acts as a neutralizer.

- For sulfuric acid, the stabilizing agent is sodium hydroxide $(\mathrm{NaOH})$.

- For cadmium, the stabilizing agent is sodium carbonate $\left(\mathrm{Na}_{2} \mathrm{CO}_{3}\right)$.

Acting as neutralizers or stabilizers, sodium sulfur, sodium hydroxide, and sodium carbonate, in equal parts, have the capacity to inhibit contaminants of any type of battery, without previous classification [17].

6) Another method of battery recycling is to reduce batteries to a pulp. The residues are mixed with water and converted to a liquid paste after being passed through a filter. The pieces of metal and other solids are extracted with a magnetic device and the pulp is introduced into a centrifuge to separate the materials. In this phase the heaviest materials are separated, like pieces of glass, and they are sent to paper and fiber recycling plants, and the remaining residue, which is a small amount of the original weight, is discarded.

\subsection{Results of the Second Phase (in laboratory)}

In the batteries collected, 12 brands and 3 to 4 sizes were differentiated. Duracell brand batteries are only found on the market in alkaline form, while only zinc-carbon Rocket batteries are sold. Panasonic batteries come in both alkaline and zinc-carbon forms. With regard to size of alkaline batteries, AA, AAA, C, and Deare sold, while zinc-carbon batteries are principally sold in AA, C, and D sizes.

Table 1 shows the average composition by part of three selected batteries, Duracell alkaline, Rocket zinc-carbon, and Bulton alkaline button battery. 
Table 1. Average values of 3 types of batteries, weight, size, and volts.

\begin{tabular}{|c|c|c|c|c|c|}
\hline No. & $\begin{array}{l}\text { Cylinder } \\
\text { Batteries }\end{array}$ & $\begin{array}{l}\text { Weight of the } \\
\text { Battery, grams }\end{array}$ & Size & Volts & $\begin{array}{c}\text { Parts of the battery, weight in } \\
\text { grams }\end{array}$ \\
\hline 1 & $\begin{array}{c}\text { Duracell. } \\
\text { (Alkaline } \\
\text { Battery }\end{array}$ & 137.5016 & $\mathrm{D}$ & 1.5 & $\begin{array}{c}\text { External plastic cover } 0.0003 \\
\text { Cap }(+) 1.0284 \\
\text { Cap } ₫-) \oplus .3 \notin 39 \\
\text { Cardboard }(-) 0.000 £ \\
\text { Empty battery } 133.34\end{array}$ \\
\hline 2 & $\begin{array}{c}\text { Rocket } \\
\text { Without } \\
\text { mercury or } \\
\text { cadmiam }\end{array}$ & 44.3000 & $\mathrm{C}$ & 1.5 & $\begin{array}{c}\text { External alumiaum cover } 6.8 \\
\text { Internal plastic cover } 0.5040 \\
\text { Aluminum cap } \$+00.9044 \\
\text { Aluminum cap }(-) 0.9872 \\
\text { Plastic caps } 0.7969 \\
\text { Cardboard (e ) } 0.000 \mathrm{e} \\
\text { Empty battery } 34.30\end{array}$ \\
\hline No. & $\begin{array}{c}\text { Button } \\
\text { batteries }\end{array}$ & $\begin{array}{l}\text { Weight of the } \\
\text { battery, grams }\end{array}$ & Size & Volts & Battery parts weight in grams \\
\hline 1 & $\begin{array}{c}\text { BULTON- } \\
\text { CELL } \\
\text { (AG13) }\end{array}$ & 1.88 & +--- & --- & $\begin{array}{c}\text { Aluminum capsuke } 1.400 \\
\text { Copper capsule } 1.42 \notin 0 \\
\text { External cover } 0.3713 \\
\text { Metallic cap } 0.3275 \\
\text { Plastic ring } 0.0605 \\
\text { Plastic cap } 0.0605 \\
\text { Cover } 0 . \notin 405 \\
\text { Empty capsule } 0.4053\end{array}$ \\
\hline
\end{tabular}

These batteries were dissected, separated, and weighed by part as explained in the Methodology section. Results show that, among their components, both batteries have isolators, packets, seals, and valves. The covers of the Duracell battery and of the button battery are stronger, as the cover is aluminium and the receptacle is steel, therefore these are more difficult to open. The Rocket battery, which is manufactured in Asia, has a very thin metal cover, it opens easily, and only one case contains the zinc-carbon components. Furthermore, the Rocket has a cardboard ring, while the Duracell and button batteries have metal rings.

The Bulton button battery, because of its size and circular shape, is more difficult to open and to separate into parts. However, once open, a zinc powder can be found under the anode plaque and below that an absorbent material that separates it from a carbon paste which is impregnated with manganese dioxide. All of this is within a small steel can.

Upon applying the dissolution technique to the batteries, using an acid solution to recuperate metals, the results were the followinge

In the button battery the following parameters and concentrations were determined $\mathrm{Cu} 3,305$ $(\mathrm{mg} / \mathrm{kg})$, Fe 23.42(mg/kg), Pb $34.52(\mathrm{mg} / \mathrm{kg})$ y Zn 7,883,655 (mg/kg), in the Rocket cylinder battery $\mathrm{Cu} 1,121(\mathrm{mg} / \mathrm{kg}), \mathrm{Pb} 21.22(\mathrm{mg} / \mathrm{kg}), \mathrm{Zn} 19,599.8(\mathrm{mg} / \mathrm{kg}), \mathrm{Cr} 0.0452(\mathrm{mg} / \mathrm{kg})$ y Ni $1,792(\mathrm{mg} / \mathrm{kg})$, and in the Duracell batteries Cu $1.021(\mathrm{mg} / \mathrm{kg})$, Fe $13.18(\mathrm{mg} / \mathrm{kg}), \mathrm{Pb} 9 . \mathrm{d} 08$ $(\mathrm{mg} / \mathrm{kg})$ y $\mathrm{Zn} 24,322(\mathrm{mg} / \mathrm{kg})$. The concentrations and weights varied according to brand, size, and type of battery (see table 2). With respect to the Rocket battery, according to specifications on its label, it does not contain mercury. Results gave a concentration of $\mathrm{Ag}$ 
$0.0096(\mathrm{mg} / \mathrm{kg})$ and in the button batteries high concentrations of mercury were obtained, Table 1 . In the literature it is reported that these contain 30 to $50 \%$ mercury $[3,5]$.

W'hen the procedure was done on the Bulton-cell battery high concentrations of copper were observed, as the dissolution took on the colour green.

Table 2. Result of the determination of metals in Cylinder and Button Batteries.

\begin{tabular}{|c|c|c|}
\hline Parameter & Method & Result (mg/kg) \\
\hline \multicolumn{3}{|c|}{ Button-bulton } \\
\hline $\mathrm{Pb}$ & EPA 7420 & 34.52 \\
\hline $\mathrm{Cu}$ & EPA 7210 & 3305 \\
\hline $\mathrm{Fe}$ & EPA 7380 & 23.42 \\
\hline $\mathrm{Zn}$ & EPA 7950 & $7,883,655$ \\
\hline $\mathrm{Ag}$ & EPA 7760 & $603,013.8$ \\
\hline $\mathrm{Cy}$ linder Duracell “D” (National) \\
\hline $\mathrm{Pb}$ & EPA 7420 & 9.108 \\
\hline $\mathrm{Cu}$ & EPA 7210 & 1.021 \\
\hline $\mathrm{Fe}$ & EPA 7380 & 13.18 \\
\hline $\mathrm{Zn}$ & EPA 7950 & 24,322 \\
\hline \multicolumn{3}{|c|}{ Cylinder Rocket “C” (Asian) } \\
\hline $\mathrm{Cr}$ & EPA 7190 & 0.0452 \\
\hline $\mathrm{Cu}$ & EPA 7210 & 1121 \\
\hline $\mathrm{Pb}$ & EPA 7420 & 21.22 \\
\hline $\mathrm{Ni}$ & EPA 7520 & 1,792 \\
\hline $\mathrm{Ag}$ & EPA 7760 & 0.0096 \\
\hline $\mathrm{Zn}$ & EPA 7950 & $19,599.8$ \\
\hline
\end{tabular}

Damage to health and to the environment has been reported for some of these metals. For example, lead in small portions causes fatigue, headaches, muscular and stomach pains, anorexia, constipation, and in its more critical phase, "lead colic," which produces intense abdominal cramping accompanied by nausea, vomiting, and elevated arterial pressure $[3,5]$. Environmental nickel provokes asthma attacks after prolonged exposure. Ingesting water with high levels of nickel cause stomach pains and adversely affects the blood and kidneys. The Department of Health and Human Services (DHHS) has determined that it is reasonable to predict that metallic nickel is carcinogenic and that its compounds are known to be carcinogenic $[3,5]$.

Chrome can reportedly be carcinogenic or an irritant. Iron can cause gastroenteritis or inflammation in the mucous membranes, nausea, vomiting, and diarrhea. Copper is not reported to have ill effects on health. Zinc, in balanced quantities, forms part of our bodies (oligoelment), but in excess of required limits can cause problems.

With the results synthesized in table 2, there is no doubt that large volumes of contaminants are emitted through improper disposal of batteries, such as 145,918 tons of eMnO2, 1,232 tons of $\mathrm{Hg}, 22,063$ tons of $\mathrm{Ni}, 20,169$ tons of $\mathrm{Cd}$, and 77 tons of $\mathrm{Li}[3,5,6]$.

\section{CONCLUSIONS}

1. There is a need for a specific norm for batteries, a general battery program that should include separation based on chemical characteristics. 
2. Despite the publication of the LGEEPA in 1988, and of the Regulation of Dangerous Wastes that regulates the handling of batteries, no programs for battery collection and recycling have yet been put into place. As such, a new law should initiate plans for management, otherwise levels of contaminants such as manganese, lead, mercury, cadmium, nickel, and lithium may reach higher levels than every before observed in air, water, and soil.

3. Few reports were identified at the level of investigation regarding development of processes related to recycle or reuse of batteries. The majority of the works refer to initiatives for the recuperation of the materials; few include adequate disposal.

4. The majority of the investigative reports only have a range of restricted application and economic questions are not approached. It is not considered that some batteries are not economically viable options for recycling, because the energy utilized in the process is not recuperated by the materials gained.

5. However, if the environmental costs of properly disposing of and/or recycling batteries are considered, economic costs become unimportant.

6. The effectiveness of recovering metals with the acid dissolution technique was confirmed. It is recommended that studies be done to purify these metals with the aim of commercialization.

\section{REFERENCES}

[1] PROFECO (1998). "Conozca cual pila comprar" Revista del Consumidor, No. 262. (In Spanish).

[2] EPA (2005). Environmental Protection Agency. Municipal Solid Waste.

[3] Jacott, M (2005) "Pilas y baterías: tóxicas en casa" www.greenpeace.org.mx. (In Spanish).

[4] Urquiza-Moreno y Ma. Neftalí Rojas-Valencia "Riesgos potenciales tanto a la salud como al ambiente por desechos de pilas eléctricas". Memorias en CD del 2do. Congreso Internacional Ambiental del Caribe. Mayo, 19, 20 y 21 de 2004:1-8. Centro de Convenciones. Cartagena de Indias- Colombia. (In Spanish).

[5] Castro y Díaz. La Contaminación por pilas y baterías en México. Gaceta Ecológica, INE- SEMARNAT México. núm. 72. México 2004. (In Spanish).

[6] Mac Kay, Nancy (2000). "Estrategias Ambientales: Las decisiones ambientales y los protagonistas" $2^{\circ}$ Parte: Derecho a la información ambiental - Capítulo 5: Crónicas de nuevos caminos.nancymac@arnet.com.ar (In Spanish).

[7] INEGI, XIV Censo Industrial. Industrias Manufactureras. Productos y Materias primas, Censos Económicos, 1995.

[8] PROFECO (1995) “Conozca quién es quién en pilas eléctricas" Revista del Consumidor. Reporte especial No. 226, diciembre. (In Spanish).

[9] Ley General del Equilibrio Ecológico y la Protección al Ambiente 1988. Diario Oficial de la Federación, 28 de enero. (In Spanish).

[10] Norma Oficial Mexicana, NOM-052-ECOL-1993, Que establece las Características de los residuos peligrosos, el listado de los mismos y los límites que hacen a un residuo peligroso por su toxicidad al ambiente. Diario Oficial de la Federación, 22 de octubre de 1993. (In Spanish).

[1I] Red Mexicana de Manejo Ambiental de Residuos (REMEXMAR), "Revisión y análisis de las experiencias nacionales respecto de los cinco elementos claves para el manejo ambiental de pilas, baterías, lubricantes y envases de plaguicidas". http://www.remexmar.org.mx. (In Spanish). 
[12] OECD Steering Group ON nickel/Cadmium Batteries, "Draft Guidance Document for Developing Successful Systems for the Collection and Recycling of Nickel/Cadmium Batteries", 1998. México.

[13] Jiménez, J. S. (2000) "Recuperación electroquímica de cadmio de mezclas de níquel y cadmio" fue la tesis de maestría de Tesis para obtener el grado de Maestro. Universidad Iberoamericana, Campus Santa Fe. (In Spanish).

[14] Santiago Osorio, Edgar. 2001. "Diseño de un reactor Batch y el proceso para tratar pilas y recuperar sus componentes". Tesis Lice(Ing. Químico)-UNAM, Facultad de Estudios Superiores Zaragoza. 115 p. (In Spanish).

[15] Mayén-Mondragón, R.; Bacza, A.; Ibanez, J. G. (2002) "Simultaneous Determination of Nickel and Cadmium by Differential Pulse Polarography" Analytical Sciences February (Japan) Vol. 18:191-193

[16] SEMARNAT, INE, Dirección General de Regulación Ambiental, Dirección de Economía Ambiental. Propuesta de sistema de depósito, Reembolso para la Gestión Ambiental de Pilas Eléctricas de Consumo familiar, 1997. (In Spanish).

[17] Marrello, P. M. (1998)"Agentes químicos estabilizadores" 2 páginas http://www.lions.org.br/circle/articulos/pilapilas.htm (In Spanish). 